\title{
The Effect Of Intellectual Capital And Islamic Performance Index On Financial Performance
}

\author{
Yusro Rahma \\ UIN Syarif Hidayatullah Jakarta \\ yusro.rahma@uinjkt.ac.id
}

\begin{abstract}
This research aims to examine intellectual capital and islamic performance index (IPI) on financial performance with profitability approach. Intellectual capital proxied by Value added intellectual capital (VAIC) (VACA, VAHU and STVA) adopted by Pulic (1998). IPI proxied by Profit Sharing Ratio (PSR), Zakat Performance Ratio (ZPR), Islamic Income Ratio (IIR), Profitability by Return on Assets (ROA). This research used 10 samples of islamic bank listed on Indonesia Financial Services Authority (OJK) in period 2012 to 2015. Multiple regression used to examine the hypothetical research. Results of this research provide evidence that value added intellectual capital (VAIC) positively and significantly influence toward return on asset. Profit Sharing Ratio (PSR) negatively and significantly no influence toward return on asset. Zakat Performance Ratio (ZPR) positively and significantly influence toward return on asset. Islamic Income Ratio (IIR) positively and significantly no influence toward return on asset with significance alpha $5 \%$, but with significance alpha $10 \%$ Islamic Income Ratio (IIR) positively and significantly influence toward return on asset

Keywords: Value Added Intellectual Capital, Profit sharing ratio, Zakat Performance Ratio, Return on Asset
\end{abstract}

\begin{abstract}
Abstrak
Penelitian ini bertujuan untuk menguji pengaruh intellectual capital dan islamic performance index (IPI) terhadap kinerja keuangan dengan pendekatan profitabilitas. Intellectual capital diproksi dengan Value added intellectual capital (VAIC) (VACA, VAHU and STVA) yang diadopsi dariPulic (1998). IPI diproksi dengan Profit Sharing Ratio (PSR), Zakat Performance Ratio (ZPR), Islamic Income Ratio (IIR), Profitabilitas dengan Return on Assets (ROA). Penelitian ini menggunakan 10 sampel bank islam yang terdaftar di Otoritas Jasa Keuangan (OJK) periode 2012 - 2015. Regresi berganda digunakan untuk menguji hipotesis penelitian. Hasil penelitian ini membuktikan bahwa value added intellectual capital (VAIC) secara positif dan signifikan berpengaruh terhadap return on asset. Profit Sharing Ratio (PSR) tidak berpengaruh signifikan terhadap return on asset. Zakat Performance Ratio (ZPR) secara positif dan signifikan berpengaruh terhadap return on asset. Islamic Income Ratio (IIR) tidak berpengaruh secara signifikan return on asset dengan tingkat signifikansi alpha 5\%, tetapi dengan tingkat signifikansi alpha 10\% Islamic Income Ratio (IIR) secara positif dan signifikan berpengaruh return on asset

Kata kunci: Value Added Intellectual Capital, Profit sharing ratio, Zakat Performance Ratio, Return on Asset
\end{abstract}

Diterima: 2018; Revisi: 2018; Disetujui: 2018 


\section{PENDAHULUAN}

Sektor perbankan syariah merupakan sektor bisnis yang bersifat "intellectually intensive" dan juga termasuk sektor jasa, di mana layanan pelanggan sangat bergantung pada intelek/akal/kecerdasan modal manuasia (Kamath, 2015). Sumber daya perbankan yang baik akan menghasilkan kinerja yang baik.

Kemajuan teknologi informasi, ilmu pengetahuan dan persaingan yang ketat, memaksa perusahaan merubah strateginya dari bisnis yang berdasarkan tenaga kerja (labor based business) ke arah bisnis yang berdasarkan ilmu pengetahuan (knowledge based business). Seiring dengan perubahan ekonomi yang berbasis pengetahuan, membuat kemamkmuran suatu perusahaan bergantung pada suatu penciptaan transformasi dan kapitalisasi pengetahuan itu sendiri (Sawarjuwono, 2003).

Pada tahun 1999, Organization for Economic Co Operation and Development (OECD) telah menyelenggarakan simposium internasional yang memfasilitasi para peneliti untuk mempresentasikan hasil kajian tentang pengukuran dan pelaporan intangible asset, termasuk intellectual capital (IC) dari berbagai negara. Dalam forum tersebut disepakati bahwa intellectual capital (IC) adalah aset yang sangat penting bagi perusahaan dalam menciptakan nilai (value) perusahaan. Di Indonesia pengungkapan tentang intellectual capital (IC) telah diatur dalam PSAK No.19 (revisi 2000) tentang aktiva tidak berwujud. Dalam standar tersebut, intellectual capital (IC) memang tidak disebutkan secara jelas. Namun makna tentang intellectual capital (IC) setidaknya telah mulai mendapat perhatian dari para regulator (Ulum, 2009).

Pulic (1998) mengajukan sebuah model pengukuran intelectual capital yang dinamakan Value Added intelectual Capital (VAIC). Model ini digunakan untuk mengukur kemampuan perusahaan dalam menciptakan efisiensi dari value added pada aset berwujud dan aset tidak berwujud yang dimiliki perusahaan sebagai hasil dari kemampuan intelektualnya. Komponen utamanya adalah Value Added Capital Employed (VACA), Value Added Human Capital (VAHU), dan Structural Capital Value Added (STVA). 
Penelitian yang dilakukan Ulum (2008) menguji pengaruh intellectual capital terhadap kinerja keuangan perbankan dan juga menguji pengaruh rata-rata pertumbuhan intellectual capital (Rate of Growth of Intellectual Capital -ROGIC) terhadap kinerja keuangan masa depan. Hasil penelitiannya menunjukkan Intellectual Capital berpengaruh terhadap kinerja perbankan masa depan.

Selain itu, Syeh Najibullah (2005) melakukan penelitian mengenai hubungan antara intellectual capital terhadap kinerja perbankan yang listing di Dhaka Stock Exchange Bangladesh. Hasil penelitiannya menunjukkan tidak terdapat hubungan yang kuat antara intellectual capital dengan kinerja perusahaan dan market value perusaahaan.

Kinerja keuangan perbankan syariah selain diukur dengan metode konvensional, juga harus diukur dari segi tujuan syariah (maqashid syariah), sehingga dapat diketahui apakah kinerja perbankan tersebut atau aktivitas muamalah yang dijalankan sesuai dengan prinsip-prinsip syariah (Abdillah, 2014). Ibrahim et al. (2003) menyajikan sebuah alternatif pengukuran kinerja untuk islamic bank yaitu dengan sebuah indeks yang dinamakan Islamicity Indices,yang terdiri dari Islamicity Disclosure Index dan Islamicity Performance Index.

Riset tentang implementasi prinsip-prinsip syariah dilakukan oleh Khan dan Mirachor (1990) dalam Suyatno (2006) terhadap bank-bank islam di Pakistan dan Iran menyimpulkan bahwa bank berdasarkan prinsip syariah tidak menyebabkan sistem keuangan runtuh atau mengkhawatirkan. Suyanto (2006), Falikhatun dan Assegaf (2012) dan Prabowo (2013) menyimpulkan bahwa pelaksanaan prinsip-prinsip syariah berpengaruh positif signifikan terhadap kinerja bank syariah dan kesejahteraan masyarakat di lingkungan kegiatan bank syariah. Penelitiannya Falikhatun dan Assegaf (2012) mengenai implementasi prinsip-prinsip syariah yang diproksi oleh Islamic Investment Ratio, Profit Sharing Financing Ratio, Islamic Income Ratio dan Director's -Employee Welfare Ratio. 


\section{METODE}

Penelitian ini bertujuan untuk menganalisa hubungan kausalitas yang digunakan untuk menjelaskan damapak intellectual capital dan islamicity performance index terhadap financial performance dengan pendekatan maqashid syariah dan profitabilitas. Populasi penelitian ini adalah perusahaan perbankan syariah di Indonesia tahun 2012 - 2015.

Dalam penelitian ini model yang digunakan adalah analisis regresi berganda (multiple regression analysis). Analisis regresi berganda digunakan untuk menguji hubungan dan pengaruh yang dihasilkan dari beberapa variabel independen terhadap satu variabel dependen. Model regresi yang digunakan untuk menguji hipotesis dalam penelitian ini telah dirumuskan sebagai berikut :

$$
\mathrm{ROA}=\beta_{0}+\beta_{1} \mathrm{VAIC}+\beta_{2} \mathrm{PSR}+\beta_{2} \mathrm{ZPR}+\beta_{2} \mathrm{IIR}+\varepsilon
$$

Keterangan:

VAIC $=$ Value Added Intellectual Capital $\rightarrow$ Pulic (1998)

PSR $=$ Profit Sharing Ratio $\rightarrow$ Hameed et.al. (2004)

ZPR = Zakat Performance Ratio $\rightarrow$ Hameed et.al. (2004)

IIR = Islamic Income Ratio $\rightarrow$ Hameed et.al. (2004)

ROA = Return on Asset $\rightarrow$ Keown et.al (2008)

Populasi dalam penelitian ini adalah Bank Umum Syariah yang terdaftar di OJK periode 2012 s.d 2015. Metode pemilihan sampel dalam penelitian ini adalah metode penelitian sampel non-probability, yaitu dengan pendekatan metode purposive sampling, artinya bahwa populasi yang akan dijadikan sampel peneltian ini adalah populasi yang memenuhi kriteria sampel tertentu .

Data yang digunakan dalam penelitian ini adalah data sekunder yang diambil dari laporan tahunan Bank Umum Syariah yang terdaftar di OJK tahun 2012 s.d 2015. Data sekunder ini merupakan data yang sudah diolah pihak perusahaan dan sudah diterbitkan dalam bentuk laporan keuangan atau dengan kata lain data yang tidak secara langsung diambil dari perusahaan yang bersangkutan yaitu di dapat dari lembaga (instansi) terkait yaitu Bursa Efek Indonesia dan dengan cara download di situs www.idx.co.id. Selain itu kepustakaan 
ini dilakukan dengan mencari dan mengumpulkan berbagai literatur. Seperti buku, artikel, jurnal dan data dari internet.

Metode analisis data dalam penelitian ini adalah dengan mengguanakan perhitungan statistik, yaitu dengan penerapan SPSS. Setelah data-data yang diperlukan dalam penelitian ini terkumpul, maka selanjutnya dilakukan analisis data yang terdiri dari metode statistik deskriptif, uji asumsi klasik, dan uji hipotesis.

\section{HASIL DAN PEMBAHASAN}

Penelitian ini dilakukan pada populasi perbankan syariah di Indonesia. Saat ini, tercatat ada 12 bank yang terdaftar di Otoritas Jasa Keuangan (OJK) dan menjalankan operasi bisnisnya sesuai dengan prinsip-prinsip syariah. Berikut daftar kedua belas bank syariah Terdapat pada Tabel 1.

Dari kedua belas bank syariah, 10 bank diambil sebagai sampel penelitian. Sampel merupakan entitas yang secara berkala menerbitkan laporan tahunan selama periode 2011 s.d 2014, dipublikasikan, dan dapat diakses secara umum. Dalam penelitian ini, laporan tahunan perusahaan tersebut digunakan sebagai bahan untuk dianalisis oleh peneliti.

Uji koefisien determinasi dilakukan untuk mengukur kemampuan variabel independen, yaitu Value Added Intellectual Capital (VAIC) dan Islamicity Performance Index (IPI) yang diproksi oleh Profit Sharing Ratio (PSR), Zakat Performance Ratio (ZPR) dan Islamic Income Ratio (IIR) dalam menjelaskan variabel dependen, yaitu Return on Assets (ROA). Adapun hasil uji koefisien determinasi dapat dilihat dari Tabel 2.

Tabel 1. Bank Umum Syariah yang terdaftar di 0JK

\begin{tabular}{|l|l|l|l|}
\hline No. & Nama Bank & Tahun Berdiri & Kode \\
\hline 1 & Bank Muamalat Indonesia & 1992 & BMI \\
\hline
\end{tabular}




\begin{tabular}{|l|l|l|l|}
\hline 2 & Bank Syariah Mandiri & 1999 & BSM \\
\hline 3 & Bank Mega Syariah & 2004 & BMS \\
\hline 4 & Bank Rakyat Indonesia Syariah & 2008 & BRIS \\
\hline 5 & Bank Bukopin Syariah & 2008 & BSB \\
\hline 6 & Panin Bank Syariah & 2009 & PBS \\
\hline 7 & Bank Central Asia Syariah & 2010 & BCAS \\
\hline 8 & Bank Negara Indonesia Syariah & 2010 & BNIS \\
\hline 9 & Bank Jabar Banten Syariah & 2010 & BJBS \\
\hline 10 & Bank Victoria Syariah & 2010 & BVS \\
\hline 11 & Maybank Syariah Indonesia & 2010 & MSI \\
\hline 12 & Bank Tabungan Pensiun Negara Syariah & 2014 & BTPNS \\
\hline
\end{tabular}

Sumber: Data sekunder yang diolah

Hasil uji koefisien determinasi pada Tabel 2 menunjukkan nilai Adjusted R Square sebesar 0,25 nilai ini menunjukkan bahwa variabel dependen yaitu ROA dapat dijelaskan sebesar $25 \%$ oleh variabel independen yaitu Value added intellectual capital (VAIC), Profit sharing ratio (PSR), Zakat performance ratio (ZPR) dan Islamic income ratio (IIR). Sedangkan sisanya 75\% (100\% - 25\%) dijelaskan oleh variabel-variabel lain yang tidak disertakan dalam model penelitian ini.

Tabel 2. Hasil Uji Koefisien Determinasi dengan ROA

\begin{tabular}{lllll}
\hline Model & $\mathrm{R}$ & $\mathrm{R}$ Square & $\begin{array}{l}\text { Adjusted } \\
\text { Square }\end{array}$ & $\begin{array}{l}\mathrm{R} \text { Std. Error of the } \\
\text { Estimate }\end{array}$ \\
\hline 1 &, $572^{\mathrm{a}}$ &, 327 &, 250 &, 0090292 \\
\hline
\end{tabular}


Uji statistik $\mathrm{t}$ digunakan untuk mengatahui apakah dalam suatu model regresi ada atau tidaknya pengaruh dari masing-masing variabel independen secara individual terhadap variabel dependen yang diuji pada tingkat signifikansi 0,05. Jika probabilitas t lebih kecil dari 0,05 maka Ha diterima dan menolak Ho, sedangkan jika nilai probabilitas t lebih besar dari 0,05 maka Ho diterima dan menolak Ha. Berikut disajikan hasil uji statistik t yang dilakukan:

Tabel 3. Hasil Uji Statistik t dengan ROA

\begin{tabular}{|c|c|c|c|c|c|c|}
\hline & & Unstan & zed & Standardized & & \\
\hline & del & Coeffici & & Coefficients & $\mathrm{t}$ & Sig. \\
\hline & & B & Std. Error & Beta & & \\
\hline 1 & (Constant) & $-7,707$ & 4,078 & & $-1,890$ & ,067 \\
\hline & VAIC & ,003 & ,001 & 308 & 2,156 & ,038 \\
\hline & PSR & -008 & 008 & -,156 & $-1,050$ & 301 \\
\hline & ZPR & 2,369 & ,977 & ,351 & 2,424 & 021 \\
\hline & IIR & 7,715 & 4,078 & 268 & 1,892 & 067 \\
\hline
\end{tabular}

Berdasarkan tabel 3, maka diperoleh model persamaan regresi sebagai berikut: $\mathrm{ROA}=-0,707+0,003$ VAIC $-0,008$ PSR + 2,369 ZPR + 7,715 IIR

Keterangan :

ROA $=$ Return on Assets

VAIC = Value added intellectual capital

PSR $=$ Profit sharing ratio

ZPR = Zakat performance ratio

IIR = Islamic income ratio

Hipotesis pertama meneliti mengenai pengaruh Value added intellectual capital (VAIC) terhadap Return on asset (ROA). Tabel 3 menunjukkan hasil bahwa variabel VAIC menunjukkan nilai t sebesar 2,156 dengan probabilitas tingkat signifikansi sebesar 0,038 . Tingkat signifikansi tersebut lebih besar dari 0,05 yang 
artinya VAIC berpengaruh positif dan signifikan terhadap ROA dan hipotesis 1 diterima.

Hasil penelitian ini mendukung hasil penelitian sebelumnya Hermawan dan Wahyuaji (2013) yang menunjukkan semakin tinggi intellectual capital maka akan semakin tinggi pula return on asset (ROA). Sesuai dengan resource based theory yang menyatakan bahwa perusahaan yang mampu mengelola sumber daya intelektualnya dengan baik dapat menghasilkan nilai tambah dan keunggulan kompetitif, sehingga akan meningkatkan kinerja keuangan perusahaan.

Hasil penelitian ini juga sesuai dengan penelitian yang dilakukan oleh Ullum et al. (2008), Rambe (2012) dan Kamath (2015) yang menyatakan bahwa intellectual capital berpengaruh positif dan signifikan terhadap ROA.

Hipotesis kedua meneliti mengenai pengaruh Profit sharing ratio (PSR) terhadap Return on Asset (ROA). Tabel 3 menunjukkan hasil bahwa variabel PSR menunjukkan nilai $\mathrm{t}$ sebesar $-1,050$ dengan probabilitas tingkat signifikansi sebesar 0,301. Tingkat signifikansi tersebut lebih besar dari 0,05 yang artinya PSR berpengaruh negatif dan tidak signifikan terhadap ROA dan hipotesis 2 ditolak.

Hasil penelitian ini menunjukkan nilai negatif namun tidak signifikan, hal ini disebabkan pembiayaan profit sharing relatif lebih kecil dibandingkan pembiayaan jual beli. Oleh karena itu, sumbangan pendapatan bagi hasil yang diperoleh dari penyaluran pembiayaan profit sharing kurang mampu mengoptimalkan kemampuan bank umum syariah dalam menghasilkan laba. Sehingga berdampak pada penurunan ROA bank umum syariah. Hasil penelitian ini tidak sesuai dengan stakeholders theory yang menyatakan bahwa perusahaan akan mampu menjaga kinerja dan menjaga keberlangsungan hidup perusahaan dengan cara mengakomodasi keinginan dan kebutuhan stakeholders.

Hasil penelitian ini bertentangan dengan penelitian Falikhatun dan Assegaf (2012) yang menyatakan bahwa profit sharing terbukti berpengaruh positif terhadap kinerja financial perbankan syariah di Indonesia.

Hipotesis pertama meneliti mengenai pengaruh Zakat performance ratio (ZPR) terhadap Return on Assets (ROA). Tabel 3 menunjukkan hasil bahwa variabel ZPR menunjukkan nilai $\mathrm{t}$ sebesar 2,424 dengan probabilitas tingkat 
signifikansi sebesar 0,021. Tingkat signifikansi tersebut lebih kecil dari 0,05 yang artinya ZPR berpengaruh positif dan signifikan terhadap ROA dan hipotesis 3 diterima.

Hasil penelitian ini konsisten dengan penelitian Ibrahim et.al (2003) yang menyatakan bahwa penerapan prinsip-prinsip syariah akan meningkatkan kinerja keuangan bank syariah. Dalam penelitian ini, pembayaran zakat bank syariah meningkat seiring meningkatnya kekayaan yang dimiliki bank syariah sehingga akan meningkatkan profitabilitas bank syariah.. Hasil penelitian ini juga sesuai dengan penelitian yang dilakukan oleh Maisaroh (2015) yang menyatakan bahwa ZPR berpengaruh positif dan signifikan terhadap ROA.

Hipotesis keempat meneliti mengenai pengaruh Islamic Income Ratio (IIR) terhadap Return on Assets (ROA). Tabel 3 menunjukkan hasil bahwa variabel IIR menunjukkan nilai t sebesar 1,892 dengan probabilitas tingkat signifikansi sebesar 0,067. Tingkat signifikansi tersebut lebih besar dari 0,05 yang artinya IIR berpengaruh positif dan tidak signifikan terhadap ROA dan hipotesis 4 ditolak. Namun jika dengan tingkat signifikansi alpha 10\%, dapat dinyatakan bahwa IIR berpengaruh positif dan signifikan terhadap ROA karena probabilitas tingkat signifikansi sebesar 0,067 lebih kecil dari alpha $10 \%(0,10)$.

Hasil penelitian ini konsisten dengan penelitian Prabowo (2013) yang menyatakan bahwa Islamic Income Ratio tidak berpengaruh signifikan terhadap kinerja perbankan syariah pada tingkat $5 \%$.

Akan tetapi jika penelitian ini menggunakan tingkat signifikansi alpha 10\%, yang artinya Islamic Income Ratio (IIR) berpengaruh terhadap ROA, hal ini menunjukkan semakin tinggi tingkat Islamic Income Ratio (IIR) mampu meningkatkan tingkat profitabilitas perbankan syariah yang diukur dengan ROA

\section{SIMPULAN}

Hasil pengujian dan pembahasan pada bagian sebelumnya dapat diringkas sebagai berikut. Pertama, Intellectual capital berpengaruh positif dan signifikan terhadap Return on Asset (ROA). Hasil penelitian ini konsisten dengan penelitian 
Ullum et al. (2008), Rambe (2012) dan Kamath (2015) yang menyatakan bahwa intellectual capital berpengaruh positif dan signifikan terhadap ROA. Kedua, Profit Sharing Ratio berpengaruh negatif dan tidak signifikan terhadap Return on Asset (ROA). Hasil penelitian ini bertentangan dengan penelitian Falikhatun dan Assegaf (2012) yang menyatakan bahwa profit sharing terbukti berpengaruh positif terhadap kinerja financial perbankan syariah di Indonesia. Ketiga, Zakat performance ratio berpengaruh positif dan signifikan Return on Asset (ROA).

Hasil penelitian ini juga sesuai dengan penelitian yang dilakukan oleh Maisaroh (2015) yang menyatakan bahwa ZPR berpengaruh positif dan signifikan terhadap ROA. Keempat, Islamic income ratio berpengaruh positif dan tidak signifikan terhadap Return on Asset (ROA). Hasil penelitian ini Hasil penelitian ini konsisten dengan penelitian Prabowo (2013) yang menyatakan bahwa Islamic Income Ratio tidak berpengaruh signifikan terhadap kinerja perbankan syariah.

\section{PUSTAKA ACUAN}

Falikhatun dan Assegaf. (2012). Bank Syariah Di Indonesia: Ketaatan Pada Prinsipprinsip Syariah Dan Kesehatan Financial. Accounting and Management (CBAM).Vol.1 No.1 Desember 2012, 245-254.

Gitman, L.J., Dan C.J.Zutter. (2011). Principles of Managerial Finance 13th Global Edition.US: Pearson

Hameed, Shaul et. Al. (2004). “ Alternative Disclosure and Performance Measures for Islamic Bank". www.iium.edu.my

Hermawan, Sigit dan Wahyuaji, B. Maharis (2013). Analisis Pengaruh Intellectual Capital Terhadap Kemampulabaan Perusahaan Manufaktur Consumer Gooods. Call For Paper: 2013: Bidang akuntansi. Pp. 271-282

Ibrahim et al. (2003). “ Alternative Disclosure and Performance Measures for Islamic Bank". www.iium.edu.my 
Kamath, G. Bharathi. (2015). Impact of Intellectual Capital on Financial Performance and Market Valuation of Firms in India. International Letters of Social and Humanistic Sciences. ISSN:2300-2697, Vol.48,pp 107-122.

Kartika, Martha dan Hatane E. Saarce. (2013). Pengaruh Intellectual Capital Pada Profitabilitas Perusahaan Perbankan Yang Terdaftar Di Bursa Efek Indonesia Pada Tahun 2007-2011. Business Accounting Review, Vol 1 No.2, pp 14-25.

Keown,A.J., J.D. Martin dan D.F. Scott. (2008). Manajemen Keuangan : Prinsip dan Penerapan Edisi 10. Diterjemahkan oleh M.P. Widodo. Indonesia: PT. Indeks.

Maisaroh, Siti. (2015). Pengaruh Intellectual Capital dan Islamicity Performance Index terhadap Profitabilitas Perbankan Syariah Di Indonesia. Tesis Universitas Islam Negeri Maulana Malik Ibrahim.

Motilewa, Bolanle D., O.A.Onakoya, dan A.O. Oke. (2015). ICT and Gender Specific Challenge Faced by Female Enterpreneurs in Nigeria. International Journal Of Business and Social Sciences. Vol 6., No.3., hh. 97-105.

Najibullah, syed. (2005), “ An Empirical Investigation of the relationship between intellectual capital and firm" market value and financial performance: in Context of Commercial Bank in Bangladesh. School of Business Independent University, Bangladesh.

Prabowo, Sandri. (2013). Pengaruh Kepatuhan Prinsip-prinsip Syariah Terhadap Kinerja Sosial Pada Perbankan Syariah Di Indonesia.

Prasetiyo, Luhur. (2014). Corporate Social Responsibility Bank Syariah Di Indonesia. Kodefikasia, Vol.8, No.1

Pulic, A (1998). “Measuring The Performance of Intellectual Potential in Knowledge Economy". Available online at: www.vaic-on.net 
Rambe, Prima Apriliani. (2012). Pengaruh Intellectual Capital terhadap ROA Pada Bank Negara Indonesia dan Muamalat. JEMI, Vol.3, No. 2, Desember.

Sangkala. (2006). Intellectual Capital Management: Strategi Baru Membangun Daya Saing Perusahaan. Jakarta: YAPENSI.

Sawarjuwono, Tjiptohadi dan Agustine P. (2003). Intellectual Capital: Perlakuan, Pengukuran Dan Pelaporan (Sebuah Library Research). Jurnal Akuntansi dan Keuangan, Vol.5, No.1, hal.35-57.

Solikhah et.al. (2010). Implikasi Intellectual Capital terhadap Financial Performance, Growth dan Market Value: studi Empris dengan Pendekatan Simplisitic Specification. Simposium Nasional Akuntansi XIII (SNA XIII), Purwokerto:13-15 Oktober 2010.

Suyanto, M (2006). Pengaruh Pelaksanaan Prinsip Syariah Terhadap Kinerja dan Kesejahteraan Masyarakat dan Lingkungan Kegiatan Bank Syariah Di Indonesia. OPTIMAL, Vol 4, No.1, hal 23-49.

Ulum, Ihyaul et.al. (2008). Intellectual Capital Dan Kinerja Keuangan Perusahaaan: Suatu Analisis Dengan Pendekatan Partial Least Squares. Simposium Nasional Akuntansi XI Pontianak.

Ulum, Ihyaul. (2009). Intellectual Capital. Yogyakarta: Graha Ilmu. 